\title{
Quantitative Proteomic Analysis of Chromatin-Associated Factors
}

\author{
Yuzuru Shiio* and Robert N. Eisenman \\ Division of Basic Sciences, Fred Hutchinson Cancer Research Center, Seattle, Washington, USA
}

Eugene C. Yi, Sam Donohoe, David R. Goodlett, and Ruedi Aebersold

Institute for Systems Biology, Seattle, Washington, USA

A method to identify and quantify chromatin-associated proteins has been developed and applied to the analysis of changes in chromatin-associated proteins induced by Myc oncoprotein expression in human B lymphocytes. Chromatin-enriched fractions were isolated by differential detergent/salt extraction and analyzed by ICAT reagent labeling, multi-dimensional chromatography and tandem mass spectrometry. Many known chromatin-associated regulatory factors were identified and quantified. The method will be widely applicable to various biological systems and reveal changes in chromatin-associated regulatory factors that underlie biological phenomena. (J Am Soc Mass Spectrom 2003, 14, 696-703) (c) 2003 American Society for Mass Spectrometry

$\mathrm{I}$ n eukaryotes, chromosomal DNA is wound around core histone octamers, forming a DNA protein complex called chromatin. Chromatin is the site of DNA replication and gene transcription, two fundamental cellular functions. Many growth and differentiation signals ultimately target chromatin to induce alteration in gene expression or DNA replication. It is well established that chromatin-associated regulatory factors (such as transcription and replication factors) play central roles in the regulation of cell proliferation, differentiation, senescence, and death. However, these proteins are generally expressed at very low levels and are often difficult to extract from the nucleus, which has hampered their biochemical analysis.

Quantitative proteome analysis is the global analysis of protein expression and has a number of advantages over mRNA expression analysis. It directly focuses on the actual biological effector molecules and provides information about biological systems that is not directly apparent from mRNA analysis. mRNA analysis cannot predict the modification or subcellular location of encoded proteins and there is a considerable discrepancy between mRNA and protein expression levels in eukaryotes [1]. While mRNA analysis generally analyzes all mRNA species expressed in a cell, proteomics allows the analysis of subsets of proteins that are enriched in

Published online May 21, 2003

Address reprint requests to Dr. R. N. Eisenman, Division of Basic Sciences, Fred Hutchinson Cancer Research Center, 1100 Fairview Ave. N. A2-025, Seattle, WA 98109-1024, USA. E-mail: eisenman@fhcrc.org

*Also at the Institute for Systems Biology, Seattle, WA 98103. specific biological contexts (such as organellas and subcellular fractions). The recently developed ICAT reagent technology [2, 3] has greatly expanded the range of proteins that can be analyzed (such as low abundance, hydrophobic, or highly charged proteins) and allows the accurate quantification and concurrent sequence identification of individual proteins in complex mixtures.

We have previously used ICAT reagent technology to analyze the protein expression changes induced by the Myc oncoprotein in rat fibroblasts [4]. Myc is a transcription factor implicated in the genesis of various human cancers (for reviews see [5-9]) and we have identified many functionally-related protein expression changes that may account for the effects of Myc on cell growth and morphology. These include the reduction of proteases, induction of protein synthesis pathways, and upregulation of anabolic enzymes upon Myc expression, which are predicted to lead to increased cell mass (cell growth). In addition, we observed a Mycinduced reduction in the levels of adhesion molecules, actin network proteins, and Rho pathway proteins, leading to reduced focal adhesions and actin stress fibers as well as altered morphology. In these experiments, we used whole cell extracts for global protein expression analysis, which resulted in the predominant detection of abundant cytoplasmic proteins. Nuclear proteins appeared to be underrepresented [4]. To extend the analysis of Myc-regulated proteins in mammalian cells to nuclear regulatory factors, we developed a method to identify and quantify chromatin-associated proteins by the combination of chromatin isolation and 
ICAT reagent analysis. We report here the application of this method to the quantitative analysis of chromatinassociated factors in human B lymphocytes that express a regulatable form of Myc.

\section{Experimental}

\section{Cell Culture and Preparation of Chromatin- Enriched Fractions}

P493-6 cells [10], human B lymphocytes expressing c-Myc in a tetracycline-repressible manner, were cultured in RPMI 1640 medium supplemented with 10\% fetal calf serum (FCS). P493-6 cells were arrested in G1 phase by the addition of $0.1 \mu \mathrm{g} / \mathrm{ml}$ tetracycline for $72 \mathrm{~h}$ in the presence of FCS. The cells were washed in PBS. Half of the cells were transferred to RPMI 1640 medium with $0.25 \%$ FCS to induce Myc expression (Myc-ON) and the other half were transferred to RPMI 1640 medium with $0.25 \% \mathrm{FCS}$ and $0.1 \mu \mathrm{g} / \mathrm{ml}$ tetracycline to keep Myc off (Myc-OFF). After eight $h$, the cells were harvested and chromatin-enriched fractions were prepared essentially as described [11, 12]. Briefly, $2 \times 10^{8}$ cells were collected, washed with PBS, and suspended at $4 \times 10^{7}$ cells $/ \mathrm{ml}$ in buffer A (10 mM Hepes [pH 7.9], $10 \mathrm{mM} \mathrm{KCl}, 1.5 \mathrm{mM} \mathrm{MgCl}_{2}, 0.34 \mathrm{M}$ sucrose, $10 \%$ glycerol, and protease inhibitors). Triton X-100 was added to $0.1 \%$, the cells were incubated on ice for $8 \mathrm{~min}$, and nuclei (fraction P1) were collected by centrifugation (5 min, $1300 \mathrm{~g}, 4^{\circ} \mathrm{C}$ ). The supernatant (fraction S1) was removed and the P1 nuclei were washed once in buffer A and lysed for $30 \mathrm{~min}$ in buffer B ( 3 mM EDTA, 0.2 mM EGTA, and protease inhibitors) on ice. Insoluble chromatin (fraction P3) and soluble material (fraction S3) were separated by centrifugation (5 min, $1700 \mathrm{~g}$, $4{ }^{\circ} \mathrm{C}$ ). P3 fractions were dissolved in a buffer containing $0.5 \%$ SDS and concentrated by acetone precipitation prior to ICAT reagent labeling. Note that dithiothreitol, which can inhibit ICAT reagent labeling, was omitted from chromatin preparation buffers.

\section{ICAT Reagent Labeling and Electrospray- Ionization Tandem Mass Spectrometry}

Chromatin-enriched fractions (1.5 $\mathrm{mg}$ each) prepared from ca. $2 \times 10^{8}$ cells and dissolved in labeling buffer (0.5\% SDS, $6 \mathrm{M}$ urea, $200 \mathrm{mM}$ Tris [pH 8.3], and $5 \mathrm{mM}$ EDTA) were reduced with $5 \mathrm{mM}$ tributylphosphine for $30 \mathrm{~min}$ at $37^{\circ} \mathrm{C}$ and labeled (Myc-OFF: Isotopically-light ICAT reagent; Myc-ON: isotopically-heavy ICAT reagent). The two labeled fractions were combined, proteolyzed to peptides with trypsin, and fractionated by cation-exchange chromatography. ICAT reagent-labeled peptides were purified using the biotin tag present in the reagent and analyzed by microcapillary high performance liquid chromatography-tandem mass spectrometry ( $\mu \mathrm{LC}-\mathrm{MS} / \mathrm{MS}$ ) as described [2-4, 13]. MS/MS spectra were searched against the NCBI human protein database. Peptides that displayed SEQUEST scores $>2$ and delta correlation scores $>0.1$ were further analyzed by detailed spectral analysis.

\section{Antibodies}

Anti-MAP kinase antibody, anti-NIFK antibody, and anti-RbAp48 antibody were obtained from Drs. Yoshiro Maru, Yoshihiro Yoneda, and Bruce Stillman, respectively. Anti-ATF-3 antibody (sc-188) and anti-Pax-5 antibody (sc-1974) were obtained from Santa Cruz Biotechnology.

\section{Results and Discussion}

To analyze the changes in chromatin-associated proteins induced by Myc expression, we used the human B cell line, P493-6, in which Myc can be expressed in a tetracycline-repressible manner [10]. As shown in Figure 1a, Myc expression was detectable as early as $4-8 \mathrm{~h}$ after tetracycline withdrawal. To detect early protein changes induced by Myc, we compared the chromatin protein expression before and $8 \mathrm{~h}$ after induction of Myc expression (Figure 1b). We fractionated the cells into soluble (S1) and chromatin-enriched (P3) fractions by a procedure illustrated in Figure 2a. Chromatin-enriched fractions represented $11 \%$ of the total cellular proteins under the conditions used (Figure 2b). As shown in Figure 2c, isolated chromatin-enriched (P3) fractions consisted of mainly histone proteins ( $\mathrm{H} 1, \mathrm{H} 2 \mathrm{~A}, \mathrm{H} 2 \mathrm{~B}$, $\mathrm{H} 3$, and $\mathrm{H} 4$ ) and numerous minor components. Histone proteins were absent in soluble fractions. Soluble proteins such as MAP kinase (Figure 2d), SUMO-1, and Smt3b (data not shown) were predominantly detected in the soluble fraction. Myc, which is a chromatinassociated transcription factor, was predominantly detected in the chromatin-enriched fractions (Figure $2 \mathrm{~d}$ ). These results indicate the validity of subcellular fractionation procedure used.

The chromatin-enriched fractions prepared from P493-6 cells prior to and $8 \mathrm{~h}$ following Myc induction were labeled with ICAT reagent [Myc-OFF: isotopically-light ICAT reagent; Myc-ON: isotopically-heavy ICAT reagent] (Figure 1b). As shown in Figure 2c, among the five histone species, only histone $\mathrm{H} 3$ displayed a discrete mobility shift after ICAT reagent labeling. This is consistent with the fact that only histone $\mathrm{H} 3$ contains cysteines which can be labeled with ICAT reagent and illustrates the specificity of ICAT reagent labeling. The two labeled fractions were combined, proteolyzed to peptides, and fractionated by cation-exchange chromatography. ICAT reagent-labeled peptides were purified using the biotin tag present in the reagent and analyzed by microcapillary high performance liquid chromatography-tandem mass spectrometry ( $\mu$ LC-MS/MS) $[2,3]$. Pairs of isotopically light- and heavy-labeled peptides are chemically identical, are easily visualized because they essentially coelute, and display an $8 \mathrm{Da}$ mass difference in a mass spectrometer. The relative quantification of each pep- 
hours after tetracycline withdrawal

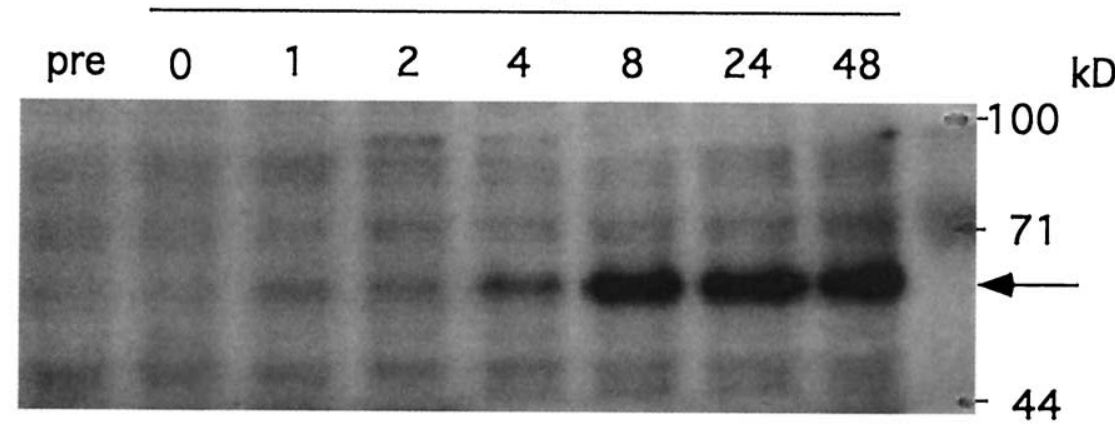

(a)

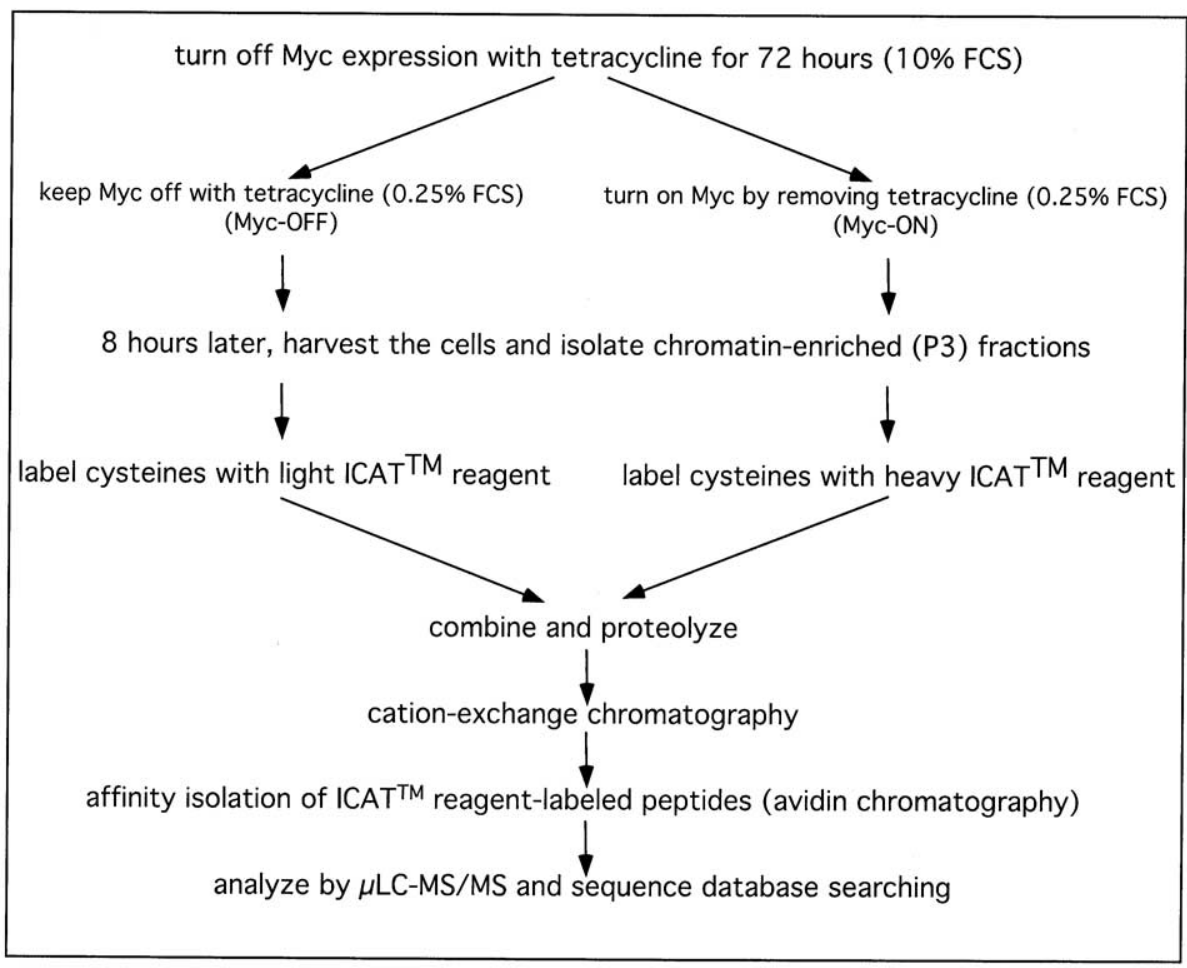

(b)

Figure 1. Analysis of chromatin protein changes in human B cells upon Myc expression. (a) Induction of Myc expression upon tetracycline withdrawal. $30 \mu \mathrm{g}$ each of the whole cell lysates prepared from P493-6 cells grown in the presence of $0.1 \mu \mathrm{g} / \mathrm{ml}$ tetracycline (pre) or the cells at the indicated time after removal of tetracycline were analyzed for Myc protein expression by anti-Myc immunoblotting. The position of the Myc protein is indicated by the arrow. (b) General procedure for ICAT reagent analysis of chromatin proteins upon Myc expression in P493-6 cells.

tide was determined by the ratio of signal intensities of peptide pairs using the Express software tool [4]. The sequence identity of the proteins in the sample was determined by correlating the tandem mass spectra of peptides with the NCBI protein database using the Sequest algorithm [14]. Together, Express and Sequest permit determination of the relative expression levels (fold increase or decrease) and the identification of the proteins.

A total of 282 proteins were identified and quantified, and of these, 64 were known nuclear proteins. These are listed in Table 1. We also detected 74 presently uncharacterized proteins that have been identified by cDNA sequencing projects, whose localization remains to be determined. Cytoplasmic proteins such as $\beta$-actin and myosin were also identified. These proteins may represent contamination by cytoplasmic proteins of the chromatin-enriched fractions. However, the presence of a number of these proteins in chromatin has not been clearly ruled out and it is possible that detection of these predominantly cytoplasmic proteins in chromatin fractions may be of some biological significance. For example, actin and actin-related proteins have recently been implicated in nuclear functions such as chromatin remodeling [15]. 


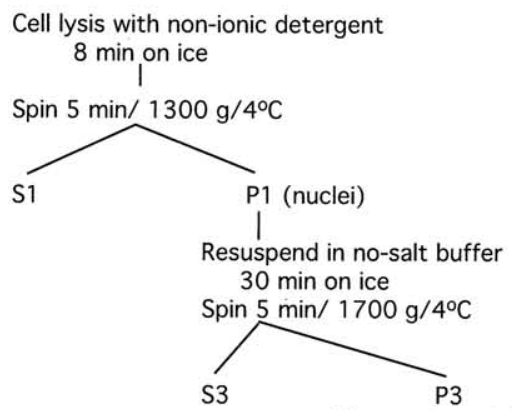

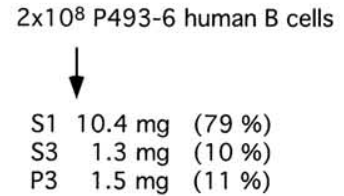

(b)

(a)

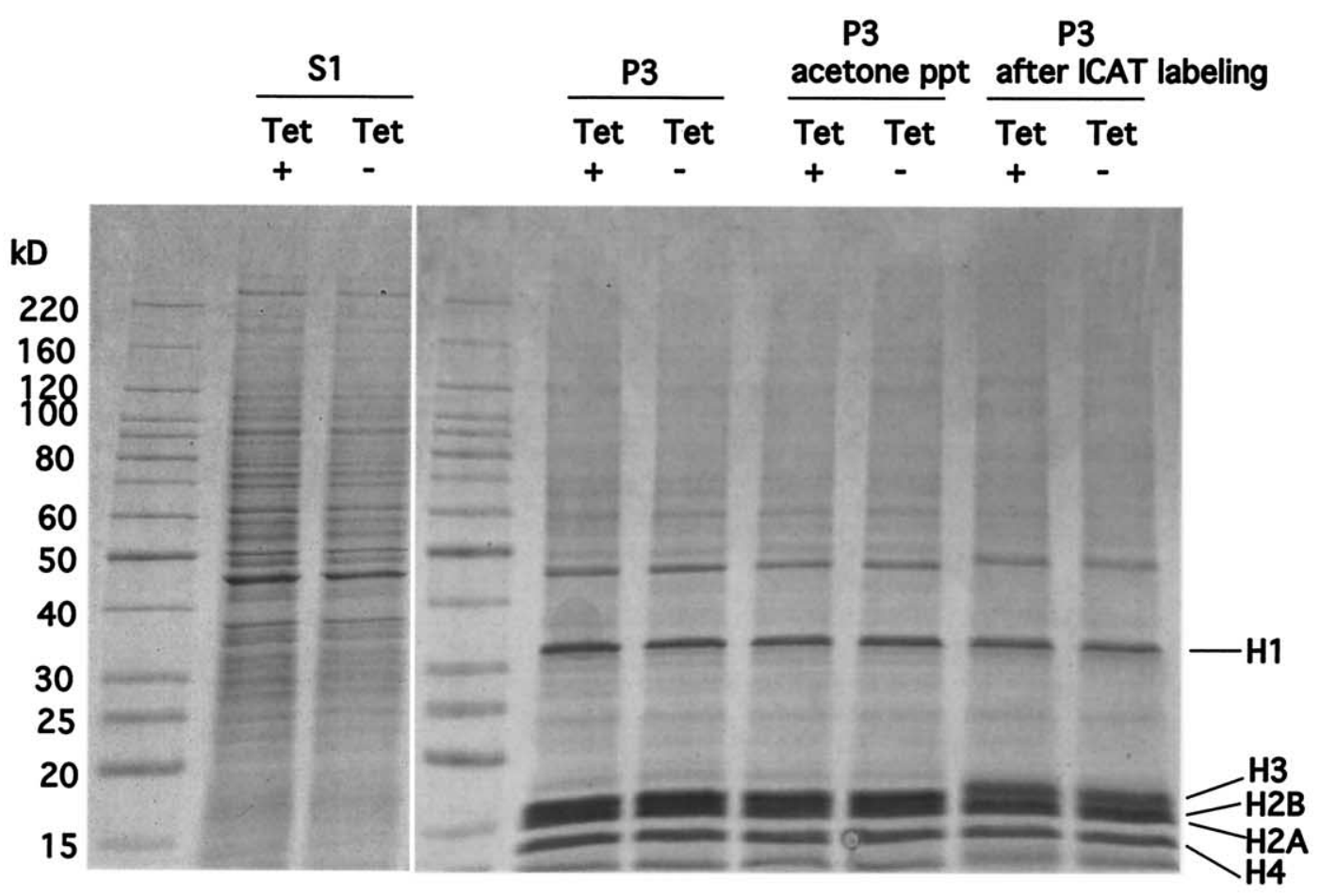

(c)

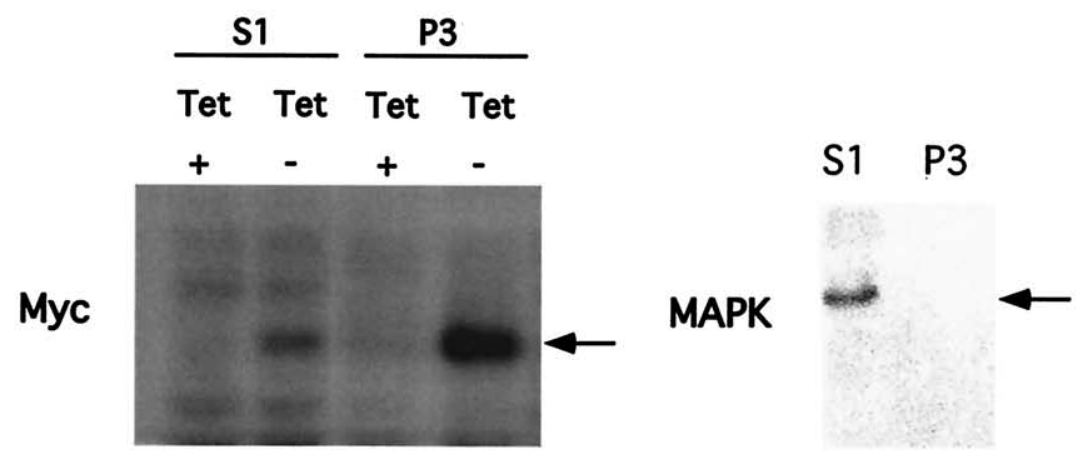

(d)

Figure 2. Preparation of chromatin-enriched fractions. (a) Cell fractionation scheme. (b) Yield of the subcellular fractions. From $2 \times 10^{8}$ P493-6 cells, $1.5 \mathrm{mg}$ of chromatin-enriched fraction was obtained, which represented $11 \%$ of the total cellular proteins. (c) Coomassie staining of the subcellular fractions. The soluble (S1) fractions and chromatin-enriched (P3) fractions before acetone precipitation, after acetone precipitation, or after ICAT reagent labeling were analyzed. The positions of histone proteins are indicated. Note that among the 5 histone species, only histone $\mathrm{H} 3$ displayed a mobility shift after ICAT reagent labeling. (d) Subcellular fractionation of Myc and MAP kinase. Subcellular fractions each prepared from $4 \times 10^{5}$ P493-6 cells were analyzed by immunoblotting. For Myc, the fractions were prepared as in Figure 1b. For MAPK, subcellular fractions of P493-6 cells growing in the medium with $10 \%$ FCS were used. Arrows indicate the position of Myc or MAPK. 


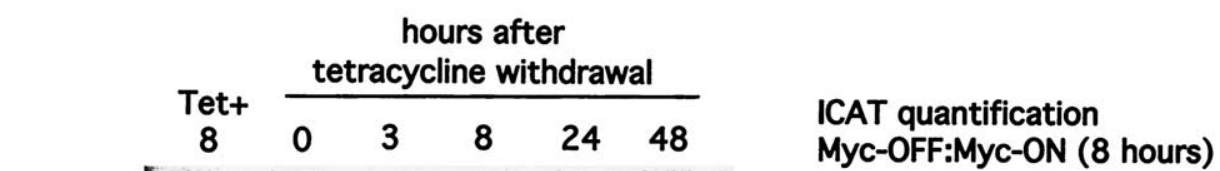

ATF-3

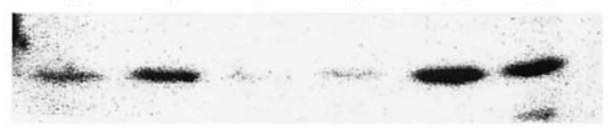
Myc-OFF:Myc-ON (8 hours)

1: 0.10

1: 2.00

hours after tetracycline withdrawal

Tet+

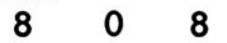

$24 \quad 48$

Pax-5

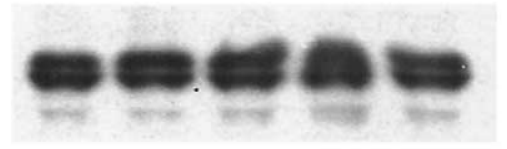

hours after tetracycline withdrawal

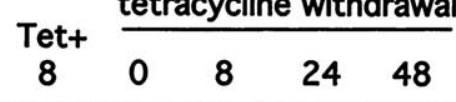

RbAp48

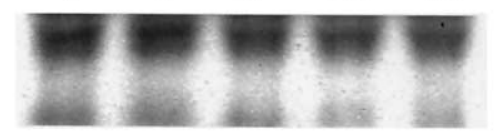

1: 0.88

1: 1.28

Figure 3. Immunoblot analysis. $30 \mu \mathrm{g}$ each of the chromatin-enriched (P3) fraction was analyzed. Mass spectrometric quantification is shown on the right.

As shown in Table 1, we were able to identify and quantify many transcription factors and other chromatin-associated regulatory factors not identified in our previous whole cell proteome analysis [4]. Histone H3 was not identified by this analysis although it was efficiently labeled with ICAT reagent (Figure 2c). This is probably due to the resistance of histones to tryptic digestion and their highly basic nature, resulting in irreversible binding to the cation exchange column. Most of the identified proteins did not display significant Myc-induced expression changes possibly because of the early time point used (only $8 \mathrm{~h}$ after Myc induction). But some proteins displayed significant expression changes and we have confirmed the reduction of ATF-3 and induction of NIFK upon Myc expression by immunoblotting (Figure 3). These protein changes were confirmed by at least three independent experiments (data not shown).

ATF-3 is a member of the CREB/ATF family of basic region leucine zipper transcription factors, which binds to cAMP responsive element (CRE) and represses transcription [16]. ATF-3 is induced in response to different stresses such as DNA damage, ischemia, wounding, and cell death inducing agents, but the consequence of ATF-3 induction is not well understood [16]. Myc expression caused a transient reduction of ATF-3 in chromatin starting as early as $3 \mathrm{~h}$ after Myc induction and ATF-3 expression returned to a basal level (or higher) at $24 \mathrm{~h}$ (Figure 3). The significance of this transient reduction of ATF-3 upon Myc expression is currently unclear. However, the very early onset of ATF-3 reduction upon Myc expression might suggest some direct regulation. We also observed reduction of ATF-3 in rat fibroblasts stably expressing Myc, suggesting that the downregulation of ATF-3 by Myc is a function of Myc common to inducible Myc expression in human B cells and constitutive Myc expression in rat fibroblasts (unpublished results).

NIFK is a nucleolar/nuclear protein that was identified as an interactor of the forkhead associated domain of Ki-67 nucleolar antigen [17]. Myc expression caused a gradual increase of NIFK protein levels in chromatin (Figure 3). Since NIFK is a nucleolar protein that binds Ki-67, which is a marker of cell proliferation, induction 
Table 1. Nuclear proteins

\begin{tabular}{|c|c|c|c|c|}
\hline \multirow[b]{3}{*}{ Category } & \multirow[b]{3}{*}{ Protein name } & \multicolumn{2}{|l|}{$(\mathrm{L}):(\mathrm{H})^{\mathrm{ab}}$} & \multirow[b]{3}{*}{ Notes } \\
\hline & & Mye-OFF:Mye-ON & & \\
\hline & & Ratio & $n^{b}$ & \\
\hline \multirow[t]{18}{*}{ Transcription } & ATF-3 & 1: 0.10 & 1 & CREB/ATE family transcription factor \\
\hline & NY-BR-1 & 1: 0.21 & 1 & Nuclear bZip, breast cancer antigen \\
\hline & Dachshund & 1: 0.43 & 1 & Human dachschund homologue \\
\hline & NREBP & 1: 0.48 & 1 & HBV NRE-binding transcriptional repressor \\
\hline & B3-1 & 1: 0.82 & 1 & Leucine zipper domain protein \\
\hline & Trithorax & 1: 0.83 & 1 & $\begin{array}{l}\text { Required for correct expression of homeotic } \\
\text { genes }\end{array}$ \\
\hline & Pax-5 & 1: 0.88 & 1 & Bcell specific transcription factor \\
\hline & RNA polymerase II largest subunit & $1: 0.88$ & 1 & \\
\hline & RBP-J kappa & 1: 0.98 & 1 & $\begin{array}{l}\text { A target of Notch, Notch converts RBP-J kappa to } \\
\text { an activator }\end{array}$ \\
\hline & CTCF & 1: 0.99 & 1 & Transcriptional repressor of the c-myc promoter \\
\hline & Androgen receptor & 1: 1.00 & 1 & \\
\hline & RFXA & $1: 1.08 \pm 0.00$ & 2 & MHC class II transcription factor \\
\hline & BAZ1B & 1: $1.11 \pm 0.16$ & 2 & Bromodomain adjacent to zinc finger 1B \\
\hline & TFII-I & 1: 1.12 & 1 & Implicated in initiator-dependent transcription \\
\hline & Sox-LZ & 1: 1.25 & 1 & $\begin{array}{l}\text { Transcription factor with leucine zipper and HMG } \\
\text { box }\end{array}$ \\
\hline & ZFP92 & 1: 1.33 & 1 & Zinc finger protein 92 \\
\hline & Brn-3a & 1: 1.64 & 1 & Brain specific homeobox/pou-domain protein $3 a$ \\
\hline & Progesteron receptor & 1: 2.10 & 1 & \\
\hline \multirow[t]{15}{*}{ Chromatin } & DNA topoisomerase II a & 1: $0.68 \pm 0.02$ & 2 & \\
\hline & CBP & 1: $0.69 \pm 0.04$ & 2 & $\begin{array}{l}\text { Transcriptional coactivator, histone acetyl } \\
\text { transferase }\end{array}$ \\
\hline & KIF4A & 1: 0.89 & 1 & Chromosome associated kinesin \\
\hline & $\mathrm{CHD} 3 / \mathrm{Mi}-2 \alpha$ & 1: 0.90 & 1 & $\begin{array}{l}\text { DNA helicase, component of } \mathrm{Mi}-2 \text { histone } \\
\text { deacetylase complex }\end{array}$ \\
\hline & $\mathrm{CHD} 4 / \mathrm{Mi}-2 \beta$ & $1: 0.90 \pm 0.03$ & 2 & $\begin{array}{l}\text { DNA helicase, component of Mi-2 histone } \\
\text { deacetylase complex }\end{array}$ \\
\hline & RbAP46 & 1: 0.91 & 1 & $\begin{array}{l}\text { Histone binding protein, recruits HAT, HDAC, and } \\
\text { CAF to histones }\end{array}$ \\
\hline & CENP-C & $1: 0.92 \pm 0.10$ & 2 & Centromere binding protein \\
\hline & p300 & 1: 1.00 & 1 & $\begin{array}{l}\text { Transcriptional coactivator, histone acetyl } \\
\text { transferase }\end{array}$ \\
\hline & PARP & $1: 1.04 \pm 0.065$ & 5 & Poly ADP-ribose polymerase \\
\hline & DNA topoisomerase I & $1: 1.07 \pm 0.08$ & 3 & \\
\hline & Histone macro h2a.1 & $1: 1.09 \pm 0.03$ & 3 & $\begin{array}{l}\text { Histone } \mathrm{H} 2 \mathrm{~A} \text { variant enriched in inactive } \mathrm{X} \\
\text { chromosome }\end{array}$ \\
\hline & SMC1 & $1: 1.18 \pm 0.13$ & 4 & $\begin{array}{l}\text { Component of condensin complex, chromosomal } \\
\text { condensation }\end{array}$ \\
\hline & $\mathrm{RCC1}$ & $1: 1.24 \pm 0.02$ & 2 & $\begin{array}{l}\text { Regulator of chromosomal condensation, GEF for } \\
\text { nuclear G-protein, ran }\end{array}$ \\
\hline & DNA topoisomerase Ilb & 1: $1.27 \pm 0.01$ & 2 & \\
\hline & $\mathrm{RbAP48}$ & 1: 1.28 & 1 & $\begin{array}{l}\text { Histone binding protein, recruits HAT, HDAC, and } \\
\text { CAF to histones }\end{array}$ \\
\hline Replication & GANP & 1: $1.15 \pm 0.10$ & 2 & DNA primase that binds MCM-3 \\
\hline \multirow[t]{4}{*}{ DNA repair } & DNA-PKc & 1: 0.76 & 1 & $\begin{array}{l}\text { Catalytic subunit of DNA-dependent protein } \\
\text { kinase }\end{array}$ \\
\hline & $\mathrm{XRCC2}$ & 1: 0.86 & 1 & $\begin{array}{l}\text { Involved in the homologous recombination repair } \\
\text { of double-stranded DNA }\end{array}$ \\
\hline & 53BP1 & $1: 1.07 \pm 0.00$ & 2 & $\begin{array}{l}\text { p53 binding protein, ATM substrate, involved in } \\
\text { DNA damage signalling }\end{array}$ \\
\hline & Uracil DNA glycosylase 2 & 1: 2.03 & 1 & Excises uracil residues from the DNA \\
\hline Splicing & Sip1 & 1: 1.45 & 1 & SR domain containing splicing factor \\
\hline \multirow[t]{2}{*}{ Nuclear matrix } & NMP200 & 1: 0.76 & 1 & Nuclear matrix protein 200 \\
\hline & NMP238 & 1: $0.78 \pm 0.00$ & 2 & Nuclear matrix protein 238 \\
\hline \multirow[t]{4}{*}{ Nuclear membrane } & RanBP2 & $1: 0.75 \pm 0.08$ & 3 & Ran-binding protein 2 \\
\hline & Nup88 & 1: 0.82 & 1 & Nuclear pore protein 88 \\
\hline & Iamin A & $1: 0.82 \pm 0.01$ & 2 & Component of the nuclear lamina \\
\hline & Iamin B1 & $1: 0.92 \pm 0.08$ & 5 & Component of the nuclear lamina \\
\hline
\end{tabular}


Table 1. (continued)

\begin{tabular}{|c|c|c|c|c|}
\hline \multirow[b]{3}{*}{ Category } & \multirow[b]{3}{*}{ Protein name } & \multicolumn{2}{|l|}{$(\mathrm{L}):(H)^{\mathrm{ab}}$} & \multirow[b]{3}{*}{ Notes } \\
\hline & & Mye-OFF:Mye-ON & & \\
\hline & & Ratio & $\mathrm{n}^{\mathrm{b}}$ & \\
\hline & Iamin B2 & $1: 0.95 \pm 0.03$ & 2 & Component of the nuclear lamina \\
\hline & Nup 155 & $1: 1.28 \pm 0.00$ & 2 & Nuclear pore protein 155 \\
\hline \multirow[t]{6}{*}{ Nucleolus } & fibrillarin & $1: 0.81 \pm 0.03$ & 2 & Involved in ribosome biogenesis \\
\hline & Nop56 & $1: 0.92 \pm 0.02$ & 2 & Required for rRNA processing and assembly \\
\hline & DDX17 & 1: 0.96 & 1 & RNA helicase \\
\hline & RNA helicase p47 & 1: 1.21 & 1 & RNA helicase \\
\hline & DDX9 & 1: $1.32 \pm 0.02$ & 2 & RNA helicase \\
\hline & NIFK & 1: 2.00 & 1 & $\begin{array}{l}\text { Nucleolar protein interacting with the FHA } \\
\text { domain of Ki-67 }\end{array}$ \\
\hline \multirow[t]{3}{*}{ hnRNP } & hnRNP H & $1: 0.69 \pm 0.17$ & 3 & \\
\hline & hnRNP U & 1: 0.73 & 1 & \\
\hline & hnRNP M & $1: 1.31 \pm 0.16$ & 2 & \\
\hline \multirow[t]{8}{*}{ Other nuclear } & PLRG1 & 1: 0.40 & 1 & $\begin{array}{l}\text { Pleiotrophic regulator } 1 \text {, implicated in SNF1 and } \\
\text { CDC5 pathways }\end{array}$ \\
\hline & BRCA1 & 1: 0.54 & 1 & Breast cancer gene 1, tumor suppressor \\
\hline & P2G4 & $1: 0.72 \pm 0.03$ & 2 & Proliferation-associated protein 2G4 \\
\hline & VRK1 & $1: 0.78 \pm 0.01$ & 2 & Nuclear Ser/Thr kinase, phosphorylates p53 \\
\hline & Cip1-interacting Zn finger protein & 1: 0.78 & 1 & Nuclear protein np94 \\
\hline & YL-1 & 1: 0.85 & 1 & Nuclear DNA binding protein \\
\hline & NuMA & 1: 1.02 & 1 & Nuclear mitotic apparatus protein \\
\hline & c-Abl & 1: 1.00 & 1 & $\begin{array}{l}\text { Proto-oncoprotein, nuclear protein tyrosine } \\
\text { kinase }\end{array}$ \\
\hline
\end{tabular}

aThe ratio of light ICAT reagent labeled peptide (L) (derived from Myc-OFF cells) and heavy ICAT reagent labeled peptide (H) (derived from Myc-ON cells) is shown together with the standard deviation.

${ }^{\mathrm{b}}$ Based on the number of independent peptides $(n)$ identified and quantified.

of NIFK by Myc may have some role in upregulation of ribosome biogenesis and protein synthesis by Myc.

We have also confirmed that there is little or no change in the expression levels of B cell specific transcription factor, Pax-5 and histone escort protein, $\mathrm{RbAp} 48$ by immunoblotting (Figure 3 ).

These results indicate that a combination of chromatin isolation and ICAT reagent analysis allows identification and accurate quantification of rare chromatinassociated regulatory factors.

Our previous analyses indicated that ICAT quantification is highly reliable and reproducible $[2,3,18,19]$. In the case of the analysis of Halobacterium total protein extracts [18], a second ICAT analysis was performed wherein the labeling of the two protein samples was reversed with respect to the light and heavy ICAT reagents, and essentially the same results as in the first ICAT analysis were obtained. There is also a good correlation between ICAT quantification and quantification by immunoblotting ([4], this paper, and unpublished results). However, since the ICAT reagent technology is still in the early phase of development, we would like to suggest that at the present stage, the method described in this paper should be regarded as a screening step to identify potentially interesting chromatin protein changes, which need to be independently confirmed by immunoblotting before they can be considered confirmed data.

\section{Conclusions}

We have developed a method to identify and quantify chromatin-associated regulatory factors by a combination of chromatin isolation and ICAT reagent analysis. Using this method, we have identified many chromatinassociated proteins and assessed the effect of Myc expression on their presence in chromatin. Most of the identified proteins did not display significant expression changes, suggesting that Myc does not robustly affect chromatin protein expression. However, some potentially interesting changes were observed. Chromatin-associated proteins were barely detected in our previous whole proteome analysis [4], indicating the necessity of directly analyzing chromatin-enriched fractions for detection of chromatin-associated factors with the current technology. Our chromatin-ICAT reagent analysis method will be useful in various biological systems by identifying changes in chromatin-associated regulatory factors which underlie biological phenomena. We are now in the process of quantitative analysis of chromatin proteins during the cell cycle and cell death.

\section{Acknowledgments}

The authors thank Dr. Dirk Eick for P493-6 cell line, Dr. Yoshiro Maru for anti-MAPK antibody, Dr. Yoshihiro Yoneda for antiNIFK antibody, and Dr. Bruce Stillman for anti-RbAp48 antibody. This work was supported by grants from NIH (DRG, RA, RNE), by Federal Fund from the National Heart, Blood and Lung 
Institute, by NIH under contract N01-HV-28179, by a grant from Oxford Glycosciences, by the Interdisciplinary Research Training Fellowship from the Fred Hutchinson Cancer Research Center (YS), and by a gift from Merck and Co. to the Institute for Systems Biology. RNE is a research professor of the American Cancer Society.

\section{References}

1. Gygi, S. P.; Rochon, Y.; Franza, B. R.; Aebersold, R. Correlation Between Protein and mRNA Abundance in Yeast. Mol. Cell. Biol. 1999, 19, 1720-1730.

2. Gygi, S. P.; Rist, B.; Gerber, S. A.; Turecek, F.; Gelb, M. H.; Aebersold, R. Quantitative Analysis of Complex Protein Mixtures Using Isotope-Coded Affinity Tags. Nat. Biotechnol. 1999, 17, 994-999.

3. Han, D. K.; Eng, J.; Zhou, H.; Aebersold, R. Quantitative Profiling of Differentiation-Induced Microsomal Proteins Using Isotope-Coded Affinity Tags and Mass Spectrometry. Nat. Biotechnol. 2001, 19, 946-951.

4. Shiio, Y.; Donohoe, S.; Yi, E. C.; Goodlett, D. R.; Aebersold, R.; Eisenman, R. N. Quantitative Proteomic Analysis of Myc Oncoprotein Function. EMBO J. 2002, 19, 5088-5096.

5. Nesbit, C. E.; Tersak, J. M.; Prochownik, E. V. MYC Oncogenes and Human Neoplastic Disease. Oncogene 1999, 18, 3004-3016.

6. Amati, B.; Frank, S. R.; Donjerkovic, D.; Taubert, S. Function of the c-Myc Oncoprotein in Chromatin Remodeling and Transcription. Biochim. Biophys. Acta 2001, 1471, M135-145.

7. Eisenman, R. N. Deconstructing Myc. Genes Dev. 2001, 15, 2023-2030.

8. Luscher, B. Function and Regulation of the Transcription Factors of the Myc/Max/Mad Network. Gene 2001, 277, 1-14.

9. Oster, S. K.; Ho, C. S.; Soucie, E. L.; Penn, L. Z. The Myc Oncogene: Marvelously Complex. Adv. Cancer Res. 2002, 84, 81-154.

10. Schuhmacher, M.; Staege, M. S.; Pajic, A.; Polack, A.; Weidle, U. H.; Bonkamm, G. W.; Eick, D.; Kohlhuber, F. Control of Cell
Growth by c-Myc in the Absence of Cell Division. Current Biol. 1999, 9, 1255-1258.

11. Mendez, J.; Stillman, B. Chromatin Association of Human Origin Recognition Complex, cdc6, and Minichromosome Maintenance Proteins During the Cell Cycle: Assembly of Prereplication Complexes in Late Mitosis. Mol. Cell. Biol. 2000, 20, 8602-8612.

12. Wysocka, J.; Reilly, P. T.; Herr, W. Loss of HCF-1-Chromatin Association Precedes Temperature-Induced Growth Arrest of tsBN67 Cells. Mol. Cell. Biol. 2001, 21, 3820-3829.

13. Yi, E. C.; Marelli, M.; Lee, H.; Purvine, S. O.; Aebersold, R.; Aitchison, J. D.; Goodlett, D. R. Approaching Complete Peroxisome Characterization by Gas-Phase Fractionation. Electrophoresis 2002, 23, 3205-3216.

14. Eng, J.; McCormack, A. L.; Yates, J. R. An Approach to Correlate Tandem Mass Spectral Data of Peptides with Amino Acid Sequences in a Protein Database. J. Am. Soc. Mass Spectrom. 1994, 5, 976-989.

15. Olave, I. A.; Reck-Peterson, S. L.; Crabtree, G. R. Nuclear Actin and Actin-Related Proteins in Chromatin Remodeling. Annu. Rev. Biochem. 2002, 71, 755-781.

16. Hai, T.; Wolfgang, C. D.; Marsee, D. K.; Allen, A. E.; Sivaprasad, U. ATF3 and Stress Responses. Gene Expression 1999, 7, 321-335.

17. Takagi, M.; Sueishi, M.; Saiwaki, T.; Kametaka, A.; Yoneda, Y. A Novel Nucleolar Protein, NIFK, Interacts with the Forkhead Associated Domain of Ki-67 Antigen in Mitosis. J. Biol. Chem. 2001, 276, 25386-25391.

18. Baliga, N. S.; Pan, M.; Goo, Y. A.; Yi, E.; Goodlett, D. R.; Dimitrov, K.; Shannon, P.; Aebersold, R.; Ng, W. V.; Hood, L. Coordinate Regulation of Energy Transduction Modules in Halobacterium sp. Analyzed by a Global Systems Approach. Proc. Natl. Acad. Sci. U.S.A. 2002, 99, 14913-14918.

19. Guina, T.; Purvine, S. O.; Yi, E. C.; Eng, J.; Goodlett, D. R.; Aebersold, R.; Miller, S. I. Quantitative Proteomic Analysis Indicates Synthesis of a Quinolone by Pseudomonas aeruginosa Isolates from Cystic Fibrosis Airways. Proc. Natl. Acad. Sci. U.S.A. 2003, 100, 2771-2776. 